\title{
Ergenlerin Yaşam Doyumlarının Yordayıcıları Olarak Direkt ve Dolaylı Akran Baskısı ${ }^{1}$
}

\author{
DOI: 10.26466/opus.748254 \\ * \\ Mustafa Kılınç* - Kıvanç Uzun ** \\ * Dr. Öğr. Üyesi, Burdur Mehmet Akif Ersoy Üniversitesi, Eğitim Fakültesi, Burdur/Türkiye \\ E-Posta: mkilinc@mehmetakif.edu.tr ORCID: 0000-0002-2759-4916 \\ ** Öğr. Gör., Burdur Mehmet Akif Ersoy Üniversitesi, \\ Mezunlarla İlişkiler ve Kariyer Planlama Koordinatörlüğü, Burdur/Türkiye \\ E-Posta: kuzun@mehmetakif.edu.tr \\ ORCID: $\underline{0000-0002-6816-1789}$
}

\section{Öz}

Bu araştırmada, ergenlerin maruz kaldıkları direkt ve dolaylı akran baskısının; yaşam doyumlarını ne derece yordandığının belirlenmesi amaçlanmıştır. Araştırma, Burdur ilinin Merkez ilçesinde yer alan ortaögretim kurumlarında öğrenimine devam etmekte olan 289 kadın ve 237 erkek olmak üzere toplam 526 lise öğrencisi üzerinde gerçekleştirilmiştir. Çalışma grubunun yaş ortalaması 15,06'dır. Araştırmada veriler; araştırmaclların geliştirdiği kişisel bilgi formu, Yetim (1993) tarafından Türk kültürüne uyarlanan Yaşam Doyumu Ölçeği ve Kıran-Esen (2003) tarafından geliştirilmiş olan Akran Baskısı Ölçeği ile toplanmıştır. Verilerin analizinde, değgişkenlerin arasındaki ilişkinin saptanması için pearson korelasyon katsayısı ile hiyerarşik çoklu doğrusal regresyon analizi kullanılırken; farklılıkların tespitine ilişkin analiz için ise ilişkisiz örneklemler t-testi ve tek yönlü varyans analizi kullanılmış, farklılıkların kaynağını test etmek adına Tukey ve Hochberg's GT2 testlerinden yararlanılmıştır. Tüm bu istatistiksel analizlerde SPSS 20.0 programı kullanılmış olup, anlamlılık düzeyi olarak ,05 alınmıştır. Araştırma sonucunda ergenlerin yaşam doyumlarının maruz kalınan direkt ve dolaylı akran baskısı tarafından negatif yönde anlamlı şekilde yordandığı bulgusuna ulaşılmıştır. Ayrıca ergenlerin yaşam doyumlarının, algılanan sosyoekonomik düzeyleri açısından anlamlı olarak farklılaştığı; ancak cinsiyet, okul türü, sınıf düzeyi, aile yapısı ve barınılan yer değiş̧kenlerine göre anlamlı bir farkın olmadığı tespit edilmiştir. Çalışma bulguları ilgili alanyazın ışığında tartışılmıştır.

Anahtar Kelimeler: Yaşam doyumu, Direkt akran baskısı, Dolaylı akran baskısı, Ergenler

${ }^{1}$ Bu çalışma 04-06 Haziran 2020 tarihinde Burdur Mehmet Akif Ersoy Üniversitesi'nde düzenlenen 3.Uluslararası Sağılı Bilimleri ve Yaşam Kongresi'nde sözlü bildiri olarak sunulmuştur. 


\title{
Direct and Indirect Peer Pressure as the Predictors of Life Satisfaction of Adolescents
}

\begin{abstract}
In the current study, it is aimed to determine the extent to which direct and indirect peer pressure on adolescents predict their life satisfaction. The study was conducted on a total of 526 high school students (289 females and 237 males) attending high schools located in the central district of the city of Burdur. The mean age of the study group is 15,06. The data of the study were collected by the personal information form developed by the researchers, the Life Satisfaction Scale adapted to Turkish by Yetim (1993) and the Peer Pressure Scale developed by Kuran-Esen (2003). In the analysis of the collected data, while Pearson correlation coefficient and hierarchic multi-linear regression analysis were used to determine the relationships between variables, independent samples t-test and one-way variance analysis were used to determine the differences and Tukey and Hochberg's GT2 tests were used to test the source of the differences. For all the statistical analyses, SPSS 20.0 program package was used and the significance level was set to be ,05. As a result of the analyses, it was concluded that the adolescents' life satisfaction was negatively and significantly predicted by the direct and indirect peer pressures they were exposed to. Moreover, the adolescents' life satisfaction was found to be varying significantly depending on the perceived social-economic level but not varying significantly depending on gender, type of the school, grade level, family structure and place of residence. Findings of the study were discussed in light of the literature.
\end{abstract}

Keywords: Life satisfaction, Direct peer pressure, Indirect peer pressure, Adolescents 


\section{Giriş}

“Nosce te ipsum" yani "Kendinizi tanıyı". Delphi'deki (Yunanistan) Apollo Tapınağı'nın duvarlarına yazılan bu basit cümle, tüm zamanların büyük filozofları ve düşünürleri için mutluluk üzerine olan düşüncelerinde ilham kaynağı olmuştur (Povedano-Diaz, Muñiz-Rivas ve Vera-Perea, 2020). Benzer şekilde, mutluluğun peşinde koşma ve "iyi bir yaşam" elde etme psikolojinin temel misyonlarından biri olarak kabul edilir (Maslow, 2013). Büyük filozoflar, düşünürler ve psikologlar için kendini tanıma, mutluluğun peşindeki anahtar bileşenlerden biridir ve sağlıklı bir benlik kavramının oluşturulmasına yardımcı olabilir (Povedano-Diaz vd., 2020).

Psikoloji açısından, son yıllarda yapılan mutluluk çalışmaları öznel iyi oluş yapısı etrafında dönmektedir (Sin ve Lyubomirsky, 2009). 80'li yıllarda başlayarak, öznel iyi oluş ile ilgili üç temel tanımlayıcı özellik hakkında geniş bir fikir birliği ile zengin bir araştırma alanı geliştirildi: (1)Farklı yaşam alanlarında bireyin refah algısı ve refahı değerlendirmesi (aile memnuniyeti veya iş yerinde memnuniyet); (2)Sadece olumsuz yanıtların (üzüntü veya öfke) olmaması değil, olumlu duygusal tepkiler (mutluluk veya iyimserlik); ve (3)Yaşamdan memnuniyetin genel bir değerlendirmesi (yaşam doyumu) (Diener, Emmons, Larsen ve Griffin, 1985; Huebner, Suldo, Smith ve McKnight, 2004).

Öznel iyi oluşun temel göstergesi olarak kabul edilen yaşam doyumu, kişinin yaşam kalitesinin bilişsel, öznel ve kapsamlı bir değerlendirmesidir (Diener, Oishi ve Tay, 2018). Yaşam doyumu, kişinin yaşamının bir bütün olarak ve / veya spesifik yaşam alanlarının bilişsel değerlendirmesi olarak tanımlanir (Huebner, Valois, Paxton ve Drane, 2005; Myers ve Diener, 1995). Yaşam doyumu ölçümlerinden alınan yüksek puanlar genellikle mutluluğun bir göstergesi olarak kabul edilir (Proctor, Linley ve Maltby, 2009).

Ergenlerin mutluluğu üzerine çalışmalar, 1990'larda gelişen “ergenlikteki olumlu gelişme ve yeterlilikler" modelinin yoğun ilgi duyduğu bir alan olmuştur (Oliva vd., 2010). "Pozitif Gençlik Gelişimi" modeli, son yıllarda çocuklarda ve ergenlerde yaşam doyumu ile ilgili araştırmaların önemli ölçüde artmasına katkıda bulunmuştur (Lerner vd., 2019). Yaşam doyumu ölçümleri ise çok maddeli ölçeklerden küresel yaşam memnuniyetini değerlendirmeye yönelik tek sorulara kadar uzanmaktadır (Abdel-Khalek, 2006; Myers ve Diener, 1995). 
Yetişkinlerin yaşam doyumuyla ilgili zengin araştırmaların aksine, çocuk ve ergenlerde yaşam doyumu üzerine çok az çalışma yapılmıştır (Calmeiro, Camacho ve Matos, 2018; Povedano-Diaz vd., 2020; Raboteg-Šarić, BrajšaŽganec ve Šakić, 2009). Yapılan bu çalışmalarda genel olarak; ergenlerin çoğu, olumlu küresel yaşam doyumuna sahiptirler (Huebner vd., 2005). Yetişkinlerle yapılan bulgulara benzer şekilde, gençlik çalışmaları öznel iyi oluşun cinsiyet, yaş ve sosyoekonomik durum (Huebner, Drane ve Valois, 2000) gibi demografik değişkenlerle zayıf ilişkili olduğunu; yaşam doyumunun daha çok kişisel ve / veya sosyal kaynakların öznelliğinden etkilenen bir yapı olduğu ortaya koymuştur (Huebner, 1991).

Alanyazın incelendiğinde yaşam doyumunun, benlik saygısı, kontrol duygusu, iyimserlik, dışadönüklüğün iç nitelikleri ve ergenlerin ebeveynlerle ilişkilerinin kalite ölçülerini içeren çeşitli kişilerarası değişkenlerle olumlu ilişki içerisinde olduğu görülmüştür (Demo ve Acock, 1996; Shek, 1998; Shek, 2005a; Shek, 2005b; Suldo ve Huebner, 2004). Ayrıca ergenlerin okulla ve akranlarıyla yaşadıkları deneyimler gibi duygusal destek sağladığı aile dışı ilişkileri de yaşam doyumu üzerinde oldukça etkilidir (Konu vd., 2002). Genellikle "dirençlilik / dayanıklılık" başlığı altında, risk altındaki gençler arasındaki olumlu sonuçlar üzerine yapılan araştırmalar; bireye veya çevresine yönelik koruyucu faktörler olarak işlev görebilen özelliklerini tanımlamaya çalışmışlardır (Masten, 1994; Masten vd., 1999). Bu özellikler arasında, ebeveyn ile istikrarlı duygusal ilişkiler, aile dışından kişilerin sosyal desteği, öz-yeterlik ve olumlu benlik saygisı deneyimlerinden en az birinin bulunması gerektiği üzerinde önemle durulmuştur (Loesel, Bliesener ve Koeferl, 1989). Bu araştırmada yaşam doyumunu açıklarken, bireylerin ailelerinin dışında en çok vakit geçirdiği, akranlarından aldıkları ya da alamadıkları sosyal destek üzerinde durulmaya çalışlacaktır. Bu yaş döneminde ergenlerin vakitlerinin büyük bir bölümünü geçirdiği okullar; içerisinde öğrencileri, öğretmenleri ve okul yöneticilerini de barındıran organizmalardır. Şüphesiz ki okullarda öğrencilerin üzerinde etkisi en yüksek olan aktörler yine diğer öğrencilerdir. Ayrıca ergenler içinde bulundukları gelişim dönemi itibariyle okul dışında da akranlarını hayatlarının önemli bir noktasına yerleştirmektedirler (Brown, Feldman ve Elliott, 1990). Bu bağlamda ergenlerin kendi aralarındaki ilişkilerin, onların algıladıkları sosyal destek ve dolayısıyla yaşam doyumları üzerinde oldukça etkili olacağı düşünülmektedir. 
$\mathrm{Bu}$ araştırmada ergenlerin yaşam doyumları üzerinde, maruz kalınan direkt ve dolaylı akran baskısının ne ölçüde etkili olduğunun üzeride durulmaya çalışlacaktır. Ergen gelişiminde akran etkisi merkezi olarak, önemli bir rol oynar. Akran, rütbe, sınıf veya yaşta olduğu gibi birbirleriyle eşit olarak duran kişiler anlamına gelir (Kirchler vd., 1993; akt. Kıran, 2002). Ergenler, düşünme ve karar vermede çocukluk döneminden daha bağımsızdırlar; ancak arkadaşlarının, özellikle de dış kontrol odağı varsa, davranış şekillendirme etkisine karşı son derece hassastırlar. Bu bağlamda Clasen ve Brown (1985) tarafından akran baskısı, bireyin isteyip istemediği önemsenmeden bir şeyi yapması konusunda akranlarından gelen baskı olarak ifade edilmiştir. Santor, Messervey ve Kusumakar (2000) ise akran baskısını, bireyin kendi yaş grubunun etkinliklerinden bir şeyi yapma konusunda kendisine ısrar edilmesi ve bir şeyi yapma konusunda cesaretlendirilmesi şeklinde tanımlanmışlardır.

Ergenler arasındaki akran baskısı, doğrudan yaşanabileceği gibi dolaylı olarak da yaşanabilmektedir. Akran grupları, kendisine üye olan ergenleri bir şeye razı etmek için çoğu zaman kolaylıkla fark edilemeyecek olan yollar da kullanmaktadırlar. Birbirleriyle alay etmek, dedikodu yapmak, karşısındakinin istediği gibi davranmak ve özel hayatına dair tacizlerde bulunmak; akran grubunun normlarını, üyesi olan ergene dayatmak için kullandığı bazı yollardandır. Akran baskısının dolaylı yöntemleri, ergenin akranlarından etkilendiğini tam olarak anlamadan, ergen üzerinde etkisini göstermektedir (Rayn, 2000). Akranlarının ne yaptığından çok, ne yapmayı düşündügünden daha fazla etkilenen ergen yaş grubu, grup içerisindeki akranlarının tarzına uymaya çalışabilir (Fischhoff, Crowell ve Kipke, 1999). Bu bağlamda direkt veya dolaylı olsun, ergenin maruz kaldığ üzerinde olumsuz etkiler yaratacağı ve yaşam kalitesini düşüreceği öngörülmektedir.

\section{Araştırmanın Amacı}

$\mathrm{Bu}$ araştırmanın amacı: Ergenlerin, yaşam doyumlarının direkt ve dolaylı yollarla maruz kaldıkları akran baskısı tarafından yordanıp yordanmadığ1nın belirlenmesi ve yaşam doyumlarının cinsiyet, okul türü, sınıf düzeyi, algılanan sosyoekonomik düzey, aile yapısı ve barınılan yer değişkenleri 
açısından farklılaşıp farklılaşmadığının saptanmasıdır. Buna yönelik araştırma soruları aşağıda belirtilmiştir.

1. Ergenlerin yaşam doyumları ile direkt ve dolaylı akran baskısına maruz kalma düzeyleri arasında anlamlı bir ilişki var mıdır?

2. Ergenlerin direkt ve dolaylı akran baskısına maruz kalmaları, yaşam doyumlarının anlamlı birer yordayıcısı midır?

3. Ergenlerin yaşam doyumu puanları cinsiyet, okul türü, sınıf düzeyi, algılanan sosyoekonomik düzey, aile yapısı ve barınılan yer değişkenlerine göre anlamlı olarak farklılaşmakta mıdır?

\section{Araştırmanın Problemi}

Alanyazın incelendiğinde, ergenlerin yaşam doyumu olgusu: Benlik saygısı (Çeçen-Eroğul ve Türk, 2013; Rey, Extremera ve Pena, 2011; Yiğit, 2010), okula bağlanma (Savi-Çakar ve Karataş, 2017), akademik performans (Leung, McBride-Chang ve Lai, 2004), genel öz-yeterlik (Erol, 2017), sosyal kaynaklı mükemmeliyetçilik, kendini değerlendirme (Çelik, Arıcı-Özcan ve Turan, 2014), aile, arkadaşlar, okul memnuniyeti (Leung, McBride-Chang ve Lai, 2004; Raboteg-Šarić ve Šakić, 2014), umut, iyimserlik (Marques, Lopez ve Mitchell, 2013; Wong ve Lim, 2009), dışadönüklük (McKnight, Huebner ve Suldo, 2002) ve maneviyat (Kelley ve Miller, 2007; Marques vd., 2013) ile pozitif yönde ilişkili bulunmuştur.

Ayrıca ergenlerin yaşam doyumu olgusu: Depresyon (Morsünbül, 2013; Wong ve Lim, 2009), sosyal kaygı (Kermen, İlçin-Tosun ve Doğan, 2016), problemli davranış sergileme (McKnight vd., 2002), utangaçlık (Erol, 2017), problemli internet kullanımı (Cao, Sun, Wan, Hao ve Tao, 2011; Demir, Peker-Özköklü ve Aygün-Turğut, 2015; Köse, 2016), yalnızlık (Ogurlu, Birben, Öpengin ve Yalın, 2016), madde bağımlılığı (Zullig, Valois, Huebner, Oeltmann ve Drane, 2001), intihar (Valois, Zullig, Huebner ve Drane, 2004), şiddet davranışları ve şiddetli yaşam olayları (McKnight vd., 2002; Valois vd., 2001), okulda yetersizlik algısı (Çelik, Arıcı-Özcan ve Turan, 2014), çocukluk örselenme yaşantıları, öfke ifade tarzları (Çeçen-Eroğul ve Türk, 2013), boyun eğici davranışlar, otomatik düşünceler ve umutsuzluk (Tümkaya, Çelik ve Aybek, 2011) ile negatif yönde ilişkili olduğu görülmüştür.

Bu bağlamda ergenlerdeki yaşam doyumu olgusunun birçok değişkenden etkilenen, karmaşık bir yapıya sahip olduğu söylenebilmektedir. Bu 
çalışmada daha önceki çalışmalardan farklı olarak; maruz kalınan direkt ve dolaylı akran baskısının ergenlerin yaşam doyumları üzerinde ne ölçüde etkili olduğu incelenmiştir. Araştırmanın bu bakımdan özgün olduğu ve ergenlerin yaşam doyumu kavramına kuramsal açıdan katkı sunacağı söylenebilir. Bu çalışma ergenlerin yaşam doyumlarının açıklanması ve arttırılması ile ilgili yapılacak araştırmalarda dikkate alınması gereken faktörlerin ortaya konulması bakımından da önem arz etmektedir.

Ayrıca alanyazın incelendiğinde, cinsiyet (Gün ve Bayraktar, 2008; Çivitçi, 2009; Çivitci vd., 2009; Funk, Huebner ve Valois, 2006; Myers ve Diener, 1995; Süpçeler, 2016; Tümkaya vd., 2011), okul türü (Çivitçi, 2009; Gün ve Bayraktar, 2008; Süpçeler, 2016), sınıf düzeyi (Çivitçi, 2009; Çivitci vd., 2009; Süpçeler, 2016; Tümkaya vd., 2011), barınılan yer (Çivitçi, 2009; Süpçeler, 2016), algılanan sosyoekonomik düzey (Myers ve Diener, 1995; Tümkaya vd., 2011; Ünal, 2011) ve aile yapısı (Akkan, 2010; Amato ve Keith, 1991; Çivitci vd., 2009; Dingiltepe, 2009; Richardson ve McCabe, 2001; Zullig, Valois, Huebner ve Drane, 2005) demografik değişkenlerine göre ergenlerin yaşam doyumu puanlarının farklılaşıp farklılaşmadığını belirlemeye yönelik yapılmış araştırmaların sonuçlarının birbiri ile tutarlı olmadığı görülmüştür. Bu demografik değişkenlere göre ergenlerin yaşam doyumlarının anlamlı farklılaşıp farklılaşmadığının incelenmesi, alanyazında ortaya çıkan muğlâklığın giderilmesine, yaşam doyumu kavramının anlaşılmasına ve alanyazındaki bilgi birikimine farklı açılardan katkı sağlayabilecektir.

\section{Yöntem}

\section{Araştırma Modeli}

Araştırmada, Burdur ilinin Merkez ilçesinde yer alan ortaöğretim kurumlarında öğrenimine devam etmekte olan ergenlerin; yaşam doyumlarının, direkt ve dolaylı akran baskısına maruz kalma düzeyleri açısından incelenmesine yönelik olarak ilişkisel tarama modeli kullanılmıştır. İlişkisel tarama modeli iki ya da daha çok sayıda değişken arasında birlikte değişim olup olmadığını ve değişimin derecesini belirlemeyi amaçlayan araştırma modelidir (Karasar, 2012). Ayrıca ergenlerin demografik değişkenlerine göre yaşam doyumu puanları arasında anlamlı bir fark olup olmadığının belirlenmesi için nedensel karşılaştırma araştırması modeli kullanılmıştır. İnsan 
grupları arasındaki farklılıkların nedenlerini ve sonuçlarını koşullar ve katılımcllar üzerinde herhangi bir müdahale olmaksızın belirlemeyi amaçlayan çalışmalara nedensel karşılaştırma araştırması denir (Büyüköztürk, KılıçÇakmak, Akgün, Karadeniz ve Demirel, 2016). Araştırma desenini güçlendirmek amacıyla yöntemde çeşitleme yapılmıştır.

\section{Evren ve Örneklem}

Araştırmanın çalışma grubu 2019-2020 eğitim öğretim yılında, Burdur ilinin Merkez ilçesinde, ortaöğretim kurumlarında öğrenim gören ve yaş ortalaması 15,06 olan 526 öğrenciden oluşmaktadır. Örneklem seçilirken, seçkisiz örnekleme yöntemlerinden tabakalı örnekleme yöntemi kullanılmıştır. Tabakalı örnekleme, evrendeki alt grupların belirlenip bunların evren büyüklüğü içindeki oranlarıyla örneklemde temsil edilmelerini sağlamayı amaçlayan bir örnekleme yöntemidir (Büyüköztürk vd., 2016). Bu bağlamda araştırmanın evreninde bulunan 5260 öğrenciden, araştırmacıların imkânları ve sınırlılıkları (zaman, para vb.) hesaplanarak; evreni temsil gücü olduğu düşünülen \%10 oranında bir örneklem oluşturulmasına karar verilmiştir (Özen ve Gül, 2007).

Oluşturulan 526 kişilik örneklemde yer alan grupların oranı, aşağıda belirtilen formül ve örnek hesaplama ile belirlenmiştir (Özen ve Gül, 2007).

\begin{tabular}{llll}
\hline Örnek hesaplama; & & & \\
\hline & Evrendeki Sayıs1 & Tabaka Ağırlı̆̆1 & Örnekleme Alnacak Kadın Sayıs \\
\hline Cinsiyet & $\mathrm{Ni}$ & $\mathrm{Ni} / \mathrm{N}=\mathrm{ai}$ & ai x $\mathrm{n}=\mathrm{ni}$ \\
\hline Kadın & 2893 & $2893 / 5260=0,55$ & $0,55 \times 526=289$ \\
\hline
\end{tabular}

Öğrencilerin araştırmaya katılmaları hususunda gönüllülük esas alınmıştır. Çalışma grubu ile ilgili demografik bilgiler Tablo 1'de verilmiştir.

Tablo 1 incelendiğinde katılımcların \%54,90'ının ( $\mathrm{n}=289)$ kadın, $\% 45,10$ 'unun ( $\mathrm{n}=237)$ ise erkek ergenlerden oluştuğu görülmektedir. Araştırmaya katılanların \%51,50'si (n=271) anadolu lisesi, \%24,10'u (n=127) fen lisesi ve \%24,30'u ( $\mathrm{n}=128)$ ise sosyal bilimler lisesi öğrencisidir. Katılımcılarin \%35,00'i (n=184) 9.sinif, \%26,80'i (n=141) 10.sınif, \%20,20'si (n=142) 11.sınıf ve \%18,10‘u (n=95) ise 12.sınıf öğrencisidir. Araştırmaya katılanların $\% 9,30^{\prime}$ u ( $\left.n=49\right)$ yoksul, \%34,40'1 ( $\left.n=181\right)$ orta ve \%56,30'u ( $\left.n=296\right)$ ise iyi olarak sosyoekonomik düzeylerini değerlendirmektedirler. Katılımcıların 
$\% 85,60^{\prime}$ ınin ( $\left.\mathrm{n}=450\right)$ anne-babası birlikte, $\% 8,20$ 'sinin $(\mathrm{n}=43)$ anne-babası ayrı ve \%6,30'unun $(\mathrm{n}=33)$ ise anne ve/veya babası vefat etmiştir. Araştırmaya katılanların \%71,50'si ( $\mathrm{n}=376)$ ailesiyle birlikte, \%21,50'si $(\mathrm{n}=113)$ yurtta ve $\% 7,00$ 'si ( $\mathrm{n}=37)$ ise akrabalarının yanında barınmaktadır.

Tablo 1. Örnekleme ait tanımlayıcı istatistik bulgular

\begin{tabular}{|c|c|c|c|}
\hline Faktör & Değişken & $\mathrm{n}$ & $\%$ \\
\hline \multirow{2}{*}{ Cinsiyet } & Kadın & 289 & 54,90 \\
\hline & Erkek & 237 & 45,10 \\
\hline \multirow{3}{*}{ Okul Türü } & Anadolu Lisesi & 271 & 51,50 \\
\hline & Fen Lisesi & 127 & 24,10 \\
\hline & Sosyal Bilimler Lisesi & 128 & 24,30 \\
\hline \multirow{4}{*}{ Sınıf Düzeyi } & 9.sinif & 184 & 35,00 \\
\hline & 10.sinif & 141 & 26,80 \\
\hline & 11.sinif & 106 & 20,20 \\
\hline & 12.sinif & 95 & 18,10 \\
\hline \multirow{3}{*}{ SED } & Yoksul & 49 & 9,30 \\
\hline & Orta & 181 & 34,40 \\
\hline & İyi & 296 & 56,30 \\
\hline \multirow{3}{*}{ Aile Yapısı } & Anne-Baba Birlikte & 450 & 85,60 \\
\hline & Anne-Baba Ayrı & 43 & 8,20 \\
\hline & Anne ve/veya Baba Ölü & 33 & 6,30 \\
\hline \multirow{3}{*}{ Barındığı Yer } & Ailesiyle Birlikte & 376 & 71,50 \\
\hline & Yurtta & 113 & 21,50 \\
\hline & Akrabalarının Yanında & 37 & 7,00 \\
\hline Toplam Öğrenci Sayısı & & 526 & 100,00 \\
\hline
\end{tabular}

\section{Veri Toplama Araçları}

Araştırmada veri toplama araçları olarak ergenlere ilişkin demografik bilgilerin elde edildiği kişisel bilgi formu, Yaşam Doyumu Ölçeği ve Akran Baskısı Ölçeği kullanılmıştır. Araştırmada kullanılan tüm veri toplama araçları için fikir hakkı sahiplerinden e-posta yoluyla kullanım izinleri alınmıştır. Araştırmaya başlanmadan önce alınan tüm bu izinler, Etik Kurul Onayına başvuru yapılırken, başvuru dosyasına eklenmiştir. Etik Kurul Onayının alınmasından itibaren başlayan araştırma süreci boyunca yayın etiğinden kesinlikle taviz verilmemiştir.

Kişisel bilgi formu: Araştırmaya katılan ergenlerin demografik özellikleri hakkında bilgi edinmek amacıyla araştırmacılar tarafından kişisel bilgi for- 
mu geliştirilmiştir. Kişisel bilgi formunda ergenlere yönelik kişisel bilgiler (cinsiyet, okul türü, sınıf düzeyi, barınılan yer, algilanan sosyoekonomik düzey ve aile yapısı) yer almaktadır.

Yaşam doyumu ölçeği (YDÖ): YDÖ, Diener ve diğerleri (1985) tarafından, bireylerin kendi yaşam kalitelerine ilişkin bilişsel değerlendirmelerini ölçmek için geliştirilmiştir. Ölçeğin Türk kültürüne uyarlanması Yetim (1993) tarafından gerçekleştirilmiştir. Toplamda 5 maddeden oluşan ölçek, '1-Hiç uygun değil' ile '7-Tamamıla uygun' arasında değişen 7'li Likert tipinde bir kendini değerlendirme envanteridir. Ölçek tek boyutlu bir yapıya sahiptir. YDÖ'den en düşük 7 puan, en çok ise 35 puan alınabilmektedir. Ölçekten alınan puanın artması, bireydeki yaşam doyumunun yükseldiğine işaret etmektedir. Ölçek toplam varyansın \%38,00'ini açıklamaktadır. YDÖ'nün Cronbach alfa iç tutarlık katsayısı ,86' dır (Yetim, 1993).

YDÖ'nün bu çalışma kapsamında kullanılabilmesi için öncelikle güvenirlik ve geçerlik çalışmaları yapılmıştır. Güvenirlik çalışması için ölçeğin Cronbach alfa iç tutarlık katsayısı hesaplanmış ve , 87 olarak bulunmuştur. Ölçeğin yapı geçerliğinin test edilmesi için Doğrulayıcı Faktör Analizi (DFA) yapılmış ve uyum indekslerinin anlamlı olduğu görülmüştür $\left(X^{2}=1030,24, s d=394, p=, 000, X^{2} / s d=2,61, R M S E A=, 044\right)$. Bu değerler göz önüne alındığında ölçeğin araştırmada kullanılabilecek düzeyde güvenilir ve geçerli olduğu söylenebilir (Kline, 2014).

Akran baskısı ölçeği (ABÖ): ABÖ, Kıran-Esen (2003) tarafından ergenlerdeki akran baskısını belirlemek amacıyla geliştirilmiştir. Toplamda 34 maddeden oluşan ölçek, '1-Hiçbir zaman' ile '5-Her zaman' arasında değişen 5'li Likert tipinde bir kendini değerlendirme envanteridir. Ölçekten alınabilecek en düşük puan 34, en yüksek puan ise 170'tir. Ölçekten alınan puanın yükselmesi ergen üzerindeki akran baskısının yüksek olduğunu göstermektedir. Ölçek, 'direkt akran baskısı' (19 madde) ve 'dolaylı akran baskısı' (15 madde) olmak üzere iki alt boyuttan oluşmaktadır ve ölçekten toplam puan alınabilmektedir. Ölçek toplam varyansın \%40,52'sini açıklamaktadır. ABÖ’n nün genel iç tutarlık katsayısı ,90'dır. Alt boyutlarının iç tutarlık katsayıları sırasıyla; direkt akran baskısı ,89, dolaylı akran baskısı ,82' dir (KıranEsen, 2003). 
ABÖ́nün bu çalışma kapsamında kullanılabilmesi için öncelikle güvenirlik ve geçerlik çalışmaları yapılmıştır. Güvenirlik çalışması için ölçeğin Cronbach alfa iç tutarlık katsayısı hesaplanmış; genel iç tutarlık katsayı ölçeğin tamamında ,94, direkt akran baskısı alt boyutunda ,90 ve dolaylı akran baskısı alt boyutunda ise , 88 olarak bulunmuştur. Ölçeğin yapı geçerliğinin test edilmesi için DFA yapılmış ve uyum indekslerinin anlamlı olduğu görülmüştür $\left(X^{2}=2326,34, \mathrm{sd}=827, \mathrm{p}=, 000, X^{2} / \mathrm{sd}=2,81\right.$, RMSEA=,063). Bu değerler göz önüne alındığında ölçeğin araştırmada kullanılabilecek düzeyde güvenilir ve geçerli olduğu söylenebilir (Kline, 2014).

\section{Verilerin Toplanması}

Öncelikle çalışmaya başlanabilmesi için araştırmacılar tarafından Mehmet Akif Ersoy Üniversitesi Girişimsel Olmayan Klinik Araştırmalar Etik Kurulu Başkanlığından, çalışmanın etik olarak uygunluğu açısından onay alınmıştır. Daha sonra çalışmanın Burdur/Merkez'deki ortaöğretim kurumlarında sağlıklı olarak yürütülebilmesi için Etik Kurul Onayı ile beraber Burdur İl Milli Eğitim Müdürlüğü'nden gerekli izinler alınmıştır. Verilerin toplanması için araştırmacılar, örneklemde yer alan okullara bizzat gitmiştir. Araştırmacılar verilerin toplanacağı her bir sınıfa ayrı ayrı girmiş, öğrencilere araştırmanın içeriği ve ölçekler ile ilgili gerekli açıklamaları yapmıştır. Öğrencilerden gönüllülüğe esas olarak, araştırmaya katılacaklardan bilgilendirilmiş onam formları imzalı olarak alınmıştır. Daha sonra ölçeklerin, öğrenciler tarafindan doldurulması sağlanmıştır. Uygulama ortalama 20 dakika sürmüştür. Tamamlanan ölçekler incelenmiş ve öğrenciler tarafından tam olarak doldurulmayan ölçekler çalışma kapsamına alınmamıştır.

\section{Verilerin Analizi}

Veriler üzerinde istatistiki işlemlerin yapılabilmesi için öncelikle toplanan veriler SPSS 20.0 programına aktarılmıştır. Elde edilen veri setinde hatasızlık kontrol edilmiş, toplam yedi değerin olası sınırlar (ranj) içinde olmadığı tespit edilmiştir. Bu durumun veri girişi sırasında yapılan hatadan kaynaklandığı anlaşılmış ve gerekli düzeltmeler yapılmıştır (Tabachnick, Fidell ve Ullman, 2007). Veri seti, kayıp veri incelemesi için hazır hale getirilmiştir. 
Daha sonra veri setindeki kayıp veri oranı incelenmiş ve bu oranın $\% 5$ 'ten az olduğu tespit edilmiştir. Kayıp veri örüntüsünün rastlantısal dağglıp dağılmadığı kontrol edilmiş, Little's MCAR testi sonucunun beklendiği gibi anlamsız çıktığı $(p=, 122>, 05)$ ve kayıp verilerin rastlantısal dağıldığı anlaşılmıştır (Little, 1988).

Toplam kayıp verinin $\% 5$ in altında kalması ve veri setinin rastlantısal dağılmasından dolayı kayıp verilere Beklenti Maksimizasyonu (EM) ile kayıp değer ataması yapılmıştır (Tabachnick vd., 2007).

Veri setindeki uç değerlerin tespit edilmesi için tek değişkenli ve çok değişkenli uç değer incelemesi yapılmıştır. Öncelikle tek değişkenli uç değer incelemesi için z testi yapılmış, örneklem büyüklüğünün 100'den fazla olmasından dolayı $-4,0$ ile $+4,0$ arası z puanı referans değeri olarak alınmıştır (Mertler ve Vannatta, 2016). Yapılan analiz sonrasında standartlaştırılmış z puanı, $-4,0$ ile $+4,0$ aralığının dışında kalan dört anket formu çalışma kapsamından çıkartılmıştır. Daha sonra çok değişkenli uç değer incelemesi için Mahalonobis uzaklık katsayısı testi yapılmış ancak birlikte uç değer ifade eden herhangi bir veriye rastlanmamıştır (Tabachnick vd., 2007).

Veri setindeki maddelerin her birinin normallik varsayımını sağlayıp sağlamadığının test edilmesi için basıklık (Kurtosis) ve çarpıklık (Skewness) katsayılarına bakılmıştır. Verilerin tümü için basıklık ve çarpıklık katsayılarının referans değer aralığı olan $-1,0$ ve $+1,0$ arasında yer aldığı görülmüştür (Büyüköztürk, Çokluk ve Şekercioğlu, 2011). Bu bağlamda verilerin normal dağıldığını söyleyebiliriz.

Veri setinde çoklu bağlantı problemi olup olmadığını kontrol etmek için değişkenler arasındaki basit (ikili) korelasyonlara bakılmıştır. Yapılan analiz sonrasında değişkenler arasındaki ikili korelasyonların hepsinin $.90^{\prime}$ dan düşük olduğu görülmüştür (Çokluk, Şekercioğlu ve Büyüköztürk, 2014). Ayrıca veri setinde çoklu bağlantı probleminin olup olmadığının belirlenmesi için VIF ve CI değerlerine de bakılmış; tüm maddeler için VIF değerlerinin 10'dan (Webster, 1992; akt. Albayrak, 2005), CI değerlerinin de 30'dan küçük (Gujarati, 1995; akt. Albayrak, 2005) olduğu görülmüştür. Bu bağlamda değişkenler arasında çoklu bağlantı sorununun olmadığı söylenebilir.

Veriler analiz işlemleri için hazır hale getirildikten sonra; öncelikle, veri setinin içerisinden rastlantısal olarak seçilen 200 anket ile Yaşam Doyumu Ölçeğinin ve Akran Baskısı Ölçeğinin çalışma kapsamında kullanılabilmesi 
için güvenirlik ve geçerlik çalışmaları yapılmıştır. Güvenirlik değerlerinin test edilmesi için ölçeklere Cronbach alfa iç tutarlık katsayısı; geçerlik değerlerinin test edilmesi için ise LISREL 8.7 programı kullanılarak DFA yapılmıştır. Ulaşılan değerler, ölçeklerin araştırmada kullanılabilecek düzeyde güvenilir ve geçerli olduğunu göstermektedir. Bu değerler, makalenin veri toplama araçları ile ilgili kısmında sunulmaktadır.

Yapılan işlemlerle verilerin regresyon analizi için gerekli olan parametrik özellikleri karşıladığı tespit edilmiştir. Bu bağlamda araştırma sorularına cevap bulmak adına: Değişkenler arasındaki ilişkiyi saptamak için pearson korelasyon katsayısı analizi; ergenlerin direkt ve dolaylı akran baskısına maruz kalma düzeylerinin yaşam doyumlarını ne ölçüde yordadığını anlayabilmek için hiyerarşik çoklu doğrusal regresyon analizi kullanılmıştır. Verilerin homojenlik varsayımını sağlayıp sağlamadığının test edilmesi için Levene Testi yapılmış ve homojenlik varsayımının sağlandığı anlaşılmıştır $(\mathrm{p}<$,458). Bunun üzerine farklılıklara ilişkin analiz için ilişkisiz örneklemler ttesti ile tek yönlü varyans analizi (ANOVA) kullanılmıştır (Büyüköztürk, 2014). Farklılıkların kaynağını test etmek adına, örneklemin kategorilerdeki dağılımları gözetilerek; Tukey veya Hochberg's GT2 testlerinden uygun olanı kullanılmıştır (Field, 2005). Ayrıca ilişkisiz örneklemler için t-testinde Cohen'in $d$ (Cohen, 1988); tek yönlü varyans analizi için ise Omega kare (Kirk, 1996) etki büyüklüğü hesaplama formülleri kullanılmıştır. Tüm bu istatistiksel analizlerde SPSS 20.0 programı kullanılmış olup, anlamlılık düzeyi olarak ,05 alınmıştır.

\section{Bulgular}

Ergenlerin direkt ve dolaylı akran baskısına maruz kalma düzeylerinin yaşam doyumlarını ne ölçüde yordadığını anlayabilmek için hiyerarşik çoklu doğrusal regresyon analizi yapılmıştır. Regresyon analizi yapılmadan önce bağımlı ve bağımsız değişkenler arasında çoklu bağlantı sorununun olup olmadığını belirlemek amacıyla bağımlı ve bağımsız değişkenler arasındaki ikili korelasyon katsayıları hesaplanmış ve ortaya çıan sonuçlar Tablo 2'de gösterilmiştir. 
Tablo 2. Değiş̧kenler arası pearson momentler çarpımı korelasyon katsayıları

\begin{tabular}{llllll}
\hline Değişkenler & $\bar{x}$ & $\mathrm{~S}$ & 1 & 2 & 3 \\
\hline 1.Yaşam Doyumu & 21,81 & 7,50 & 1 &,$- 221^{* *}$ &,$- 255^{* *}$ \\
2.Direkt Akran Baskısı & 25,58 & 9,60 & & 1 &, $849^{* *}$ \\
3.Dolaylı Akran Baskısı & 26,18 & 9,82 & & & 1 \\
\hline
\end{tabular}

${ }^{* *} \mathrm{p}<, 01,{ }^{*} \mathrm{p}<, 05$

Tablo 2'ye göre ergenlerin yaşam doyumları ile direkt $(r=-, 211, p<, 05)$ ve dolaylı ( $\mathrm{r}=$,255, $\mathrm{p}<, 05)$ akran baskısına maruz kalma düzeyleri arasında negatif yönde anlamlı bir ilişki vardır. Bu ilişkilerin kurgulanan modelde çoklu bağlantı sorunu oluşturacak düzeyde olmadığı (,90'dan küçük olduğu); verilerin analizi bölümünde sunulmuş olan regresyon varsayımı için yapılan analizlerden de anlaşılmaktadır (Çokluk vd., 2014). Ayrıca elde edilen korelasyon katsayıları incelendiğinde, ergenlerin yaşam doyumları ile direkt ve dolaylı akran baskısına maruz kalma düzeyleri arasında düşük $(, 00<\mathrm{r}<, 30)$ düzeyde bir ilişkinin var olduğu görülmektedir (Büyüköztürk, 2014).

Ergenlerin direkt ve dolaylı akran baskısına maruz kalma düzeylerinin, yaşam doyumlarını anlamlı olarak yordayıp yordamadığını saptamak için yapılan hiyerarşik çoklu doğrusal regresyon analizinden elde edilen sonuçlar Tablo 3'te sunulmuştur.

Tablo 3. Yaşam doyumunun yordayıcılar olarak direkt ve dolaylı akran baskısına maruz kalmaya ilişkin hiyerarşik çoklu doğrusal regresyon analizi sonuçları

\begin{tabular}{|c|c|c|c|c|c|c|c|c|c|c|}
\hline Model & Yordayıcilar & B & $\mathrm{SH}$ & $\beta$ & $\mathrm{T}$ & $p$ & $\Delta R^{2}$ & $R^{2}$ & $\mathrm{~F}$ & $p$ \\
\hline $\begin{array}{l}1 . \\
\text { Mod. }\end{array}$ & $\begin{array}{l}\text { Direkt Akran } \\
\text { Baskısı }\end{array}$ & -101 & ,034 &,- 221 & $-2,727^{* *}$ & 005 & 086 & 086 & 7,122 & ,005 \\
\hline & $\begin{array}{l}\text { Direkt Akran } \\
\text { Baskıs1 }\end{array}$ & -112 & 064 & -204 & $-1,039^{*}$ & ,032 & \multirow{2}{*}{ 082 } & \multirow{2}{*}{ 168 } & \multirow{2}{*}{9,506} & \multirow{2}{*}{,002 } \\
\hline & $\begin{array}{l}\text { Dolaylı Akran } \\
\text { Baskısı }\end{array}$ & 128 & ,074 &,- 238 & $-2,865^{*}$ & 021 & & & & \\
\hline
\end{tabular}

${ }^{* *} \mathrm{p}<, 01,{ }^{*} \mathrm{p}<, 05$

Tablo 3'e görülen hiyerarşik çoklu doğrusal regresyon analizi sonuçlarına göre direkt ve dolaylı akran baskısı değişkenleri hep birlikte, ergenlerin yaşam doyumu puanlarını anlamlı olarak yordamakta ve regresyon için kurgulanan modelin anlamlı olduğu görülmektedir $\left(R=316, R^{2}=, 168\right.$, $\left.\mathrm{F}_{(2,523)}=9,506, \mathrm{p}<, 01\right)$. Kurgulanan regresyon modelinde belirtilen tüm bu de- 
ğişkenler, ergenlerin yaşam doyumları üzerinde orta düzeyde etki $\left(, 13<\mathrm{R}^{2}<, 26\right)$ değerine sahiptir (Cohen, 1988).

Tablo 3 incelendiğinde modele ilk olarak; direkt akran baskısı değişkeninin girmekte olduğu görülmektedir. Direkt akran baskısı değişkeni ergenlerin yaşam doyumlarının \%8,60'ını açıklamaktadır. İkinci adımda ise modele ek olarak, dolaylı akran baskısı değişkeninin dâhil edildiği görülmektedir. Bu adımda direkt ve dolaylı akran baskısı değişkenleri hep birlikte ergenlerin yaşam doyumlarını \%16,80'ini açıklamaktadır. Regresyon katsayılarının anlamlılığına ilişkin $\mathrm{t}$-testi sonuçları incelendiğinde; direkt ( $\mathrm{t}=-$ $1,039, \mathrm{p}<, 05)$ ve dolaylı $(\mathrm{t}=-2,865, \mathrm{p}<, 05)$ akran baskısının, ergenlerin yaşam doyumları üzerinde negatif yönde anlamlı birer yordayıcı olduğu görülmektedir.

Standardize edilmiş regresyon katsayısına $(\beta)$ göre yordayıc değişkenlerin, ergenlerin yaşam doyumları üzerindeki göreli önem sırası; dolaylı $(\beta=-$ ,238) ve direkt $(\beta=-, 204)$ akran baskısı şeklinde sıralanmaktadır. Bu sonuçlar göz önüne alındığında ergenlerin maruz kaldıkları direkt ve dolaylı akran baskısı düzeyleri arttıkça, yaşam doyumu düzeylerinin azalmakta olduğu söylenebilir.

Ergenlerin cinsiyet değişkeni açısından yaşam doyumu puanları arasındaki farkın anlamlı olup olmadığını incelenmek için ilişkisiz örneklemler ttesti analizi gerçekleştirilmiş ve sonuçlar Tablo 4 'te gösterilmiştir.

Tablo 4. Ergenlerin cinsiyet değişkeni açısından yaşam doyumu puanlarının incelenmesine yönelik ilişkisiz örneklemler t-testi sonuçlar

\begin{tabular}{lllllllll}
\hline Değişken & Cinsiyet & $\mathrm{n}$ & $\overline{\boldsymbol{x}}$ & $\mathrm{S}$ & $\mathrm{sd}$ & $\mathrm{t}$ & $\mathrm{p}$ & Cohen's d \\
\hline \multirow{2}{*}{ Yaşam Doyumu } & Kadın & 289 & 21,58 & 7,29 & \multirow{2}{*}{524} & \multirow{2}{*}{, 785} & \multirow{2}{*}{433} & \multirow{2}{*}{022} \\
& Erkek & 237 & 22,10 & 7,75 & & & & \\
\hline
\end{tabular}

Tablo 4'te görüldüğü gibi kadın ve erkek ergenlerin yaşam doyumu puanları $\left(\mathrm{t}_{(524)}=-, 785, \mathrm{p}>, 05\right)$ anlamlı olarak farklılaşmamaktadır. Bu sonuç kadın ergenlerin yaşam doyumu puan ortalamaları $(\bar{x}=21,58, \mathrm{ss}=7,29)$ ile erkek ergenlerin yaşam doyumu puan ortalamalarının $(\bar{x}=22,10$, ss $=7,75)$ birbirine çok yakın olmasından kaynaklanmış olabilir. Ayrıca Tablo 4 incelendiğinde cinsiyet değişkeninin, ergenlerin yaşam doyumu puan ortalamaları üzerindeki etki büyüklüğünün küçük $(d=, 022)$ düzeyde olduğu anlaşılmaktadır (Cohen, 1988). 
Ergenlerin öğrenim gördükleri okul türlerine göre yaşam doyumu puanları arasındaki farkın anlamlı olup olmadığını saptamaya yönelik tek yönlü varyans analizi yapılmış, sonuçlar Tablo 5'de sunulmuştur.

Tablo 5. Ergenlerin okul türlerine göre yaşam doyumu puanlarının incelenmesine ilişkin tek yönlü varyans analizi sonuçlarn

\begin{tabular}{lllllllll}
\hline Değişken & Okul Türü & $\mathrm{n}$ & $\overline{\boldsymbol{x}}$ & $\mathrm{S}$ & $\mathrm{F}$ & $\mathrm{p}$ & Fark & $\Omega^{2}$ \\
\hline \multirow{2}{*}{ Yaşam } & Anadolu Lisesi (A) & 271 & 21,47 & 7,76 & & & & \\
Doyumu & Fen Lisesi (B) & 127 & 22,02 & 7,02 & \multirow{2}{*}{, 648} & \multirow{2}{*}{, 528} & Yok & \multirow{2}{*}{022} \\
& Sosyal Bilimler Lisesi (C) & 128 & 22,34 & 7,41 & & & & \\
\hline
\end{tabular}

Tablo 5'de görüldüğü üzere ergenlerin öğrenim gördükleri okul türü ile yaşam doyumu puanları arasında bulunan fark istatistiksel olarak anlamlı değildir $\left(\mathrm{F}_{(2,523)}=, 648, \mathrm{p}>, 05\right)$. Tablo 5 incelendiğinde ergenlerin öğrenim gördükleri okul türü fark etmeksizin birbirlerine yakın düzeyde yaşam doyumu ortalamalarına sahip oldukları görülmektedir. Ayrıca Tablo 5'e bakıldığında öğrenim gördükleri okul türlerinin, ergenlerin yaşam doyumu puan ortalamaları üzerindeki etki büyüklügünü̈n küçük $\left(\Omega^{2}=, 022\right)$ düzeyde olduğu anlaşılmaktadır (Kirk, 1996).

Ergenlerin sınıf düzeylerine göre yaşam doyumu puanları arasındaki farkın anlamlı olup olmadığını saptamaya yönelik tek yönlü varyans analizi yapılmış, sonuçlar Tablo 6'da gösterilmiştir.

Tablo 6. Ergenlerin sinıf düzeylerine göre yaşam doyumu puanlarnın incelenmesine ilişkin tek yönlü varyans analizi sonuçlarn

\begin{tabular}{lllllllll}
\hline Değişken & Sınıf Düzeyi & $\mathrm{n}$ & $\overline{\boldsymbol{x}}$ & $\mathrm{S}$ & $\mathrm{F}$ & $\mathrm{p}$ & Fark & $\Omega^{2}$ \\
\hline \multirow{3}{*}{ Yaşam Doyumu } & 9.sınıf (A) & 184 & 21,70 & 7,54 & & & & \\
& 10.sınıf (B) & 141 & 22,29 & 7,38 & & & & \\
& 11.sinıf (C) & 106 & 21,02 & 7,38 &, 677 & \multirow{2}{*}{, 567} & Yok &, 019 \\
& 12.sinıf (D) & 95 & 22,21 & 7,76 & & & & \\
\hline
\end{tabular}

Tablo 6'da görüldüğü gibi ergenlerin sınıf düzeyleri ile yaşam doyumu puanları arasında bulunan fark istatistiksel olarak anlamlı değildir $(F(3,522)=, 677, p>, 05)$. Tablo 6 incelendiğinde dört sınıf düzeyi için de ergenlerin birbirlerine benzer yaşam doyumu puanlarına sahip oldukları söylenebilir. Ayrıca Tablo 6'ya bakıldığında sınıf düzeylerinin, ergenlerin yaşam doyumu puan ortalamaları üzerindeki etki büyüklügünün küçük $\left(\Omega^{2}=, 019\right)$ düzeyde olduğu anlaşılmaktadır (Kirk, 1996). 
Ergenlerin algıladıkları sosyoekonomik düzeylerine göre yaşam doyumu puanları arasındaki farkın anlamlı olup olmadığını saptamaya yönelik tek yönlü varyans analizi yapılmış, sonuçlar Tablo 7'de sunulmuştur.

Tablo 7. Ergenlerin algıladıkları sosyoekonomik düzeylerine göre yaşam doyumu puanlarının incelenmesine ilişkin tek yönlü varyans analizi sonuçlarn

\begin{tabular}{lllllllll}
\hline Değişken & Sinuf Düzeyi & $\mathrm{n}$ & $\bar{x}$ & $\mathrm{~S}$ & $\mathrm{~F}$ & $\mathrm{p}$ & Fark & $\Omega^{2}$ \\
\hline \multirow{3}{*}{ Yaşam Doyumu } & Yoksul (A) & 49 & 18,04 & 7,92 & & & A-B & \\
& Orta (B) & 181 & 20,59 & 6,91 & \multirow{2}{*}{$9,339^{* *}$} & \multirow{2}{*}{000} & B-C & \multirow{2}{*}{096} \\
& İyi (C) & 296 & 24,38 & 7,57 & & & A-C & \\
\hline
\end{tabular}

${ }^{* *} \mathrm{p}<, 01$

Tablo 7'de görüldüğü üzere ergenlerin algıladıkları sosyoekonomik durumları ile yaşam doyumu puanları arasında bulunan fark istatistiksel olarak anlamlıdır $\left(\mathrm{F}_{(2,523)}=9,339, \mathrm{p}<, 01\right)$. Tablo 7 incelendiğinde, sosyoekonomik düzeyini yüksek olarak tanımlayan ergenlerin, sosyoekonomik düzeyini düşük olarak tanımlayan ergenlere göre yaşam doyumu puan ortalamalar1nın daha yüksek olduğu söylenebilir. Ayrıca Tablo 7'ye bakıldığında algıladıkları sosyoekonomik durumlarını, ergenlerin yaşam doyumu puan ortalamaları üzerindeki etki büyüklügünün orta $\left(\Omega^{2}=, 096\right)$ düzeyde olduğu anlaşılmaktadır (Kirk, 1996).

Ergenlerin aile yapılarına göre yaşam doyumu puanları arasındaki farkın anlamlı olup olmadığını saptamaya yönelik tek yönlü varyans analizi yapılmış, sonuçlar Tablo 8'de gösterilmiştir.

Tablo 8. Ergenlerin aile yapılarnna göre yaşam doyumu puanlarnın incelenmesine ilişkin tek yönlü varyans analizi sonuçlarn

\begin{tabular}{lllllllll}
\hline Değişken & Aile Yapısı & $\mathrm{n}$ & $\overline{\boldsymbol{x}}$ & $\mathrm{S}$ & $\mathrm{F}$ & $\mathrm{p}$ & Fark & $\Omega^{2}$ \\
\hline \multirow{2}{*}{ Yaşam } & Anne-baba birlikte (A) & 450 & 21,89 & 7,45 & & & & \\
Doyumu & Anne-baba ayrı (B) & 43 & 20,86 & 8,11 & \multirow{2}{*}{, 385} & \multirow{2}{*}{681} & \multirow{2}{*}{ Yok } & \multirow{2}{*}{019} \\
& Anne ve/veya baba ölü (C) & 33 & 22,03 & 7,57 & & & & \\
\hline
\end{tabular}

Tablo 8'de görüldüğü gibi ergenlerin aile yapıları ile yaşam doyumu puanları arasında bulunan fark istatistiksel olarak anlamlı değildir $\left(\mathrm{F}_{(2,523)}=, 385\right.$, $\mathrm{p}>$,05). Bu sonuç anne-babası ayrı olan ve anne-babası hayatta olmayan ergenlerin, örneklem içerisinde yeteri kadar temsil edilememiş olmasından kaynaklanmış olabilir. Ayrıca Tablo 8 incelendiğinde aile yapılarının, ergen- 
lerin yaşam doyumu puan ortalamaları üzerindeki etki büyüklügünün küçük $\left(\Omega^{2}=, 019\right)$ düzeyde olduğu anlaşılmaktadır (Kirk, 1996).

Ergenlerin barındıkları yerlere göre yaşam doyumu puanları arasındaki farkın anlamlı olup olmadığını saptamaya yönelik tek yönlü varyans analizi yapılmış, sonuçlar Tablo 9'da sunulmuştur.

Tablo 9. Ergenlerin barndıklarn yerlere göre yaşam doyumu puanlarnın incelenmesine ilişkin tek yönlü varyans analizi sonuçları

\begin{tabular}{lllllllll}
\hline Değişken & Barınılan Yer & $\mathrm{n}$ & $\overline{\boldsymbol{x}}$ & $\mathrm{S}$ & $\mathrm{F}$ & $\mathrm{p}$ & Fark & $\Omega^{2}$ \\
\hline \multirow{2}{*}{ Yaşam } & Ailesiyle Birlikte (A) & 376 & 22,20 & 7,49 & & & & \\
Doyumu & Yurtta (B) & 113 & 20,72 & 6,97 & \multirow{2}{*}{1,804} & \multirow{2}{*}{, 166} & Yok & \multirow{2}{*}{027} \\
& Akrabalarının Yanında (C) & 37 & 21,24 & 8,91 & & & & \\
\hline
\end{tabular}

Tablo 9'da görüldüğü üzere ergenlerin barındığı yerler ile yaşam doyumu puanları arasında bulunan fark istatistiksel olarak anlamlı değildir $(\mathrm{F}(2,523)=1,804, \mathrm{p}>, 05)$. Tablo 9'a bakıldığında barındıkları yer fark etmeksizin, ergenlerin birbirine benzer düzeyde yaşam doyumu ortalamalarına sahip olduğu görülmektedir. Bunun yanında akrabalarının yanında kalan ergenlerin, örneklem içerisinde yeteri kadar temsil edilememiş olması da bu sonucun ortaya çıkmasında etkili olabilir. Ayrıca Tablo 9 incelendiğinde barınılan yer değişkeninin, ergenlerin yaşam doyumu puan ortalamaları üzerindeki etki büyüklüğünün küçük $\left(\Omega^{2}=, 027\right)$ düzeyde olduğu anlaşılmaktadir (Kirk, 1996).

\section{Tartışma ve Sonuç}

Ergenlerin yaşam doyumlarının, maruz kaldıkları direkt ve dolaylı olarak akran baskısı tarafından ne derece yordandığını incelemeyi amaçlayan bu araştırmada; maruz kalınan direkt ve dolaylı akran baskısının, ergenlerin yaşam doyumlarını negatif yönde anlamlı olarak yordadığı belirlenmiştir. Direkt ve dolaylı akran baskısına maruz kalmak, ergenlerin yaşam doyumunu; araştırmacıların beklediğinden daha düşük bir oranda yordamaktadır. Bu durumun alanyazın incelendiğinde; yaşam doyumunun, problem durumunda da belirtildiği gibi birçok faktörden etkilenen karmaşık bir yapısının olmasından ve bu şartlar altında tek bir değişkenin ergenlerin yaşam doyumu üzerinde büyük bir etki yaratamayacağından kaynaklandığı düşünülmektedir. 
Araştırmadan elde edilen bulgular, maruz kalınan direkt ve dolaylı akran baskısının; ergenlerin yaşam doyumları açısından önemli bir risk faktörü oluşturduğunu göstermektedir. Ayrıca maruz kalınan direkt ve dolaylı akran baskısının, ergenlerin yaşam doyumu düzeylerini azalttı̆̆ yani olumsuz yönde etkilediği anlaşılmıştır. Ergenlerin akranları tarafından direkt ya da dolaylı yollarla baskı görmesi, onların yaşamlarından duydukları memnuniyetin azalmasına neden olacaktır. Böylesi bir durum da kaçınılmaz sonuç ise ergenlerin yaşam doyumlarının ciddi oranda azalmasıdır.

Araştırmanin sonucunda elde edilen bulgulara paralel olarak gösterilebilecek, ergenlerin yaşam doyumları ile maruz kaldıkları direkt ve dolaylı akran baskısının birlikte incelendiği bir çalışmaya yurt içinde ve yurt dışında rastlanılmamıştır. Çalışma bu yönüyle özgündür. Ancak alanyazın incelendiğinde, araştırma konusuna yakın olduğu ve araştırmanın bulgularını destekleyeceği düşünülen bazı çalışmalara ulaşılmıştır. Proctor ve diğerlerinin (2010) ergenler üzerinde yürütmüş oldukları araştırmada ortaya çıkan, olumlu akran ilişkilerinin yüksek düzeyde yaşam doyumuyla; olumsuz akran ilişkilerinin ise düşük düzeydeki yaşam doyumuyla anlamlı düzeyde ilişkili olduğu sonucu, araştırmanın bulgularını destekler niteliktedir. Ayrıca Çivitçi (2009) bireylerin arkadaşlık ilişkileri açısından, hoşnut olup olmadıklarına ilişkin yaptıkları genel bilişsel değerlendirmelerin; yaşam doyumları üzerinde önemli bir belirleyici olduğunu ifade etmiştir. Paxton, Valois, Huebner ve Drene (2006) ise ergenlerin, yaşamlarının herhangi bir alanında karşılaştıkları sosyal baskının; onların yaşam doyumlarının azalmasına neden olduğunu belirtmişlerdir. Son olarak Gilman ve Huebner (2006), araştırmalarında yüksek yaşam doyumuna sahip ergenlerin özelliklerini incelemişlerdir ve sonuç olarak yasam doyumu ile olumlu kişilerarası ilişkiler arasında pozitif yönde anlamlı ilişkiler olduğunu tespit etmişlerdir. Tüm bu bulgular, maruz kalınan direkt ve dolaylı akran baskısının; ergenlerin yaşam doyumları üzerindeki olumsuz etkisinin, alanyazın tarafından da desteklendiğini göstermektedir.

Araştırmanin sonucunda elde edilen bir diğer bulgu ise; ergenlerin yaşam doyumlarının algıladıkları sosyoekonomik düzeylerine göre anlamlı olarak farklılaştığı sonucudur. Ulaşılan sonuçlara göre sosyoekonomik düzeyini yüksek olarak tanımlayan ergenlerin, sosyoekonomik düzeyini düşük olarak tanımlayan ergenlere göre yaşam doyumlarının daha yüksek olduğu görülmektedir. Bu bağlamda farklı sosyoekonomik düzey algısına 
sahip olan ergenlerin, farklı yaşam kalitelerine sahip oldukları düşünülmektedir. Genel anlamda düşük sosyoekonomik düzey algisına sahip ergenlerin, içinde bulundukları kötü ekonomik şartlardan dolayı yaşam doyumlarının düşük olabileceği söylenebilir. Düşük sosyoekonomik düzey algısına sahip ergenlerin, maddi imkânlarının kötü olmasından dolayı herhangi bir şeye ulaşmaları konusunda çok fazla çaba sarf etmeleri gerektiği için yaşamdan memnuniyetlerinin de buna bağlı olarak düşmesi beklenmektedir. Yüksek sosyoekonomik düzey algısına sahip ergenlerin ise yaşamlarından aldıkları memnuniyeti engelleyecek veya sekteye uğratacak herhangi bir çaba, emek ve feragat gibi süreçlerin içerisine girmemeleri, yaşam doyumlarının yüksek olmasına neden olmuş olabilir. Araştırmanın bulgularına paralel olarak: Tümkaya ve diğerleri (2011) tarafından yapılmış olan araştırmada elde edilen; ergenlerin yaşam doyumlarının, sahip oldukları gelir düzeyinin yükselmesi ile beraber anlamlı olarak farklılaştığı sonucu gösterilebilir. Ayrıca Ünal (2011), bireylerin yaşam doyumunu etkileyen unsurların başında, ekonomik güvenliğin de olduğunu ifade edilmiştir. Ancak alanyazın incelendiğinde, araştırmanın bulgularına aykırı olarak: Myers ve Diener (1995), ergenlerin yaşam doyumu ile ilgili yapıkları çalışmada; gelir durumunun, yaşam doyumunu yordama da hemen hemen hiçbir etkisinin olmadığı sonucuna ulaşmışlardır.

Araştırmanın sonucunda elde edilen diğer bulgulara göre ergenlerin yaşam doyumlarının; cinsiyet, okul türü, sınıf düzeyi, aile yapısı ve barınılan yer değişkenleri açısından anlamlı olarak farklılaşmadı̆̆ tespit edilmiştir. Bu sonuç yaşam doyumu kavramının birçok değişkenden etkilenen karmaşık ve çok yönlü bir yapısının olmasından kaynaklandığı şeklinde yorumlanabilir. Problem durumunda da belirtildiği gibi ergenlerin yaşam doyumların birçok değişkenin etkisi altındadır. Bu bağlamda yukarıda belirtilen demografik değişkenlerin tek başlarına, ergenlerin yaşam doyumları üzerinde farklılaşma yaratacak etki gücüne sahip olmadıkları söylenebilir. Alanyazın incelendiğinde araştırmanın bulgularına paralel olarak, ergenlerin yaşam doyumlarının; cinsiyet (Çivitçi, 2009; Çivitci vd., 2009; Funk vd., 2006; Gün ve Bayraktar, 2008; Myers ve Diener, 1995; Süpçeler, 2016; Tümkaya vd., 2011), okul türü (Gün ve Bayraktar, 2008), sınıf düzeyi (Çivitçi, 2009; Çivitci vd., 2009; Tümkaya vd., 2011), aile yapısı (Akkan, 2010) ve barınılan yer (Süpçeler, 2016) değişkenleri açısından farklılaşmadığı sonucuna ulaşan çalışmaların var olduğu görülmektedir. Ancak alanyazında, araştır- 
manın bulgularına aykırı olarak; okul türü (Çivitçi, 2009; Süpçeler, 2016), sınıf düzeyi (Çivitçi, 2009; Süpçeler, 2016), aile yapısı (Amato ve Keith, 1991; Çivitci vd., 2009; Dingiltepe, 2009; Richardson ve McCabe, 2001; Zullig vd., 2005) ve barınılan yer (Çivitçi, 2009) değişkenlerinin ergenlerin yaşam doyumları üzerinde fark yarattığına dair çalışmalarda mevcuttur. Alanyazında ortaya çıkan bu muğlâklığın, çalışmaların yapıldığı; genelde kültürden, özelde ise örneklemden kaynaklandığı düşünülmektedir.

\section{Öneriler}

Araştırma sonuçlarına göre şu öneriler sıralanabilir;

Bu çalışmada sosyoekonomik düzeyini yüksek olarak algilayan ergenlerin, düşük sosyoekonomik düzey algısına sahip ergenlere göre yaşam doyumu puanları yüksek bulunduğundan; sosyoekonomik düzeyini düşük olarak algılayan ergenlere, yaşam doyumlarını arttırabilecek psikoeğitim programları oluşturulabilir. Bu programların içeriği hazırlanırken, ergenlerin direkt ve dolaylı yollarla maruz kaldıkları akran baskısıyla nasıl başa çıkabileceklerine dair beceriler geliştirebilecekleri etkinliklere özellikle yer verilebilir.

Araştırma, nitel araştırma yaklaşımıyla planlanarak farklı bir boyut kazandırılabilir. Böylece ergenlerle derinlemesine görüşmeler ya da odak grup görüşmeleri yapılarak yaşam doyumu ve akran baskısı arasındaki ilişkiye dair elde edilen bulgular zenginleştirilebilir.

Alanyazın incelendiğinde, ergenlerin yaşam doyumları ile maruz kalınan direkt ve dolaylı akran baskısının birlikte incelendiği bir çalışmanın olmadığ1 görülmüştür. Bundan dolayı bu araştırmada ergenlerin yaşam doyumlarını yordayan direkt ve dolaylı akran baskısı değişkenleri üzerinde çalışılmıştır. Daha sonra yapılması planlanan araştırmalarda, farklı değişkenlerin (psikolojik zihinlilik, ruminasyon vb.) üzerinde durulmasl; ergenlerin yaşam doyumlarının daha iyi anlaşılmasına katkı sağlayabilir. 


\title{
EXTENDED ABSTRACT
}

\section{Direct and Indirect Peer Pressure as the Predictors of Life Satisfaction of Adolescents}

\author{
Mustafa Kılınç - Kıvanç Uzun \\ Burdur Mehmet Akif Ersoy University
}

Life satisfaction of Adolescents is expected to yield meaningful changes in their academic and social lives. In this context, it becomes important to investigate possible risk factors that may occur in the circle of friends of adolescents and harm their life satisfaction. Thus, some light can be shed for the preventive studies to be conducted on possible risk factors that may harm adolescents' life satisfaction.

The purpose of the current study is to determine whether adolescents' life satisfaction is predicted by peer pressure that they are directly and indirectly exposed to and whether their life satisfaction varies significantly depending on the following variables; gender, type of the school attended, grade level, socio-economic level, family structure and place of residence.

The current study employed the relational survey model to investigate whether adolescents' life satisfaction is predicted by peer pressure that they are directly and indirectly exposed to. Moreover, the causal comparative research model was used to determine whether the adolescents' life satisfaction scores vary significantly depending on some demographic variables and triangulation was capitalized on to strengthen the research design.

The study group of the current research is comprised of 526 students attending secondary schools in the central district of the city of Burdur in the 2019-2020 school year and the mean age of the participating students is 15,06 . While selecting the sample, the stratified sampling method, one of the random sampling methods, was used. The data of the study were collected by using the personal information form developed by the researchers, the Life Satisfaction Scale adapted to the Turkish culture by Yetim (1993) and the Peer Pressure Scale developed by Kiran-Esen (2003). 
In the analysis of the collected data, Pearson correlation coefficient and hierarchical multiple linear regression analysis were used to determine the relationships between the variables; independent samples t-test and oneway variance analysis were used to determine the differences and to test the source of the differences, Tukey and Hochberg's GT2 tests were used. For all these statistical analyses, SPSS 20.0 program package was used and the significance level was set to be, 05 .

When the paired correlation coefficients between the dependent and independent variables were calculated, a negative and significant correlation was found between the adolescents' life satisfaction and exposure to direct peer pressure $(\mathrm{r}=-\mathrm{-}, 211, \mathrm{p}<, 05)$ and indirect peer pressure $(\mathrm{r}=-, 255$, $\mathrm{p}<, 05)$. When the obtained correlation coefficients were examined, a low correlation was found between the adolescents' life satisfaction and their exposure to direct and indirect peer pressure $(, 00<\mathrm{r}<, 30)$ (Büyüköztürk, 2014).

According to the results of the hierarchical multiple linear regression analysis, the variables of direct and indirect peer pressure together significantly predict the adolescents' life satisfaction scores and the model established for the regression seems to be significant $\left(R=, 316, R^{2}=, 168\right.$, $\left.\mathrm{F}_{(2,523)}=9,506, \mathrm{p}<, 01\right)$. All these variables in the formulated regression model have a medium level effect on the adolescents' life satisfaction $\left(, 13<\mathrm{R}^{2}<, 26\right)$ (Cohen, 1988). The variables of direct and indirect peer pressure together explain $16,80 \%$ of the variance in the adolescents' life satisfaction. When the results of the $t$-test conducted to determine the significance of regression coefficients are examined, it is seen that direct peer pressure $(t=-1,039$, $\mathrm{p}<, 05)$ and indirect peer pressure $(t=-2,865, \mathrm{p}<, 05)$ are negative and significant predictors of the adolescents' life satisfaction.

The order of the relative importance of the predictor variables on the adolescents' life satisfaction according to the standardized regression coefficient $(\beta)$ is as follows; indirect peer pressure $(\beta=-, 238)$ and direct peer pressure $(\beta=-, 204)$. In light of these results, it can be argued that with increasing levels of direct and indirect peer pressure, adolescents' life satisfaction level decreases.

Another finding of the current study is that the adolescents' life satisfaction varies significantly depending on their perceived socio-economic levels. The life satisfaction of the adolescents who described their socio- 
economic level as high is significantly higher than that of the adolescents who described their socio-economic level as low. This might be because the adolescents who have the perception of low socio-economic level have to work hard to achieve something as their economic situations are bad; thus, their life satisfaction is low. Moreover, it was found that the adolescents' life satisfaction does not vary significantly depending on gender, type of the school attended, grade level, family structure and place of residence. This might be because the concept of life satisfaction has a complex and multi-faceted structure affected by many variables. As stated in the problem statement, adolescents' life satisfaction is under the influence of many variables. In this regard, it can be said that the above-mentioned variables cannot create a significant effect on adolescents' life satisfaction on their own.

In the explanation of adolescents' life satisfaction, direct peer pressure and indirect peer pressure were found to have an important role. This finding contributes to the understanding of potential risk sources of adolescents' life satisfaction. Furthermore, the fact that the life satisfaction scores of the adolescents whose socio-economic level is low are significantly lower can shed light on the comprehensive preventive activities to be directed to these adolescents.

\section{Kaynakça / References}

Abdel-Khalek, A. M. (2006). Measuring happiness with a single item-scale. Social Behavior and Personality, 34(2), 139-150. doi:10.2224/sbp.2006.34.2.139

Akkan, E. (2010). Ortägretimdeki üstün yetenekli ögrencilerin duygusal zeka ve yaratıcllk düzeylerinin yasam doyumlarmı yordama gücü. Yayımlanmamıs Yüksek Lisans Tezi. Gaziosmanpaşa Üniversitesi, Sosyal Bilimler Enstitüsü, Tokat.

Albayrak, A. S. (2005). Çoklu doğrusal bağlantı halinde enküçük kareler tekniğinin alternatifi yanlı tahmin teknikleri ve bir uygulama. ZKÜ Sosyal Bilimler Dergisi, 1(1), 105-126.

Amato, P. R. ve Keith, B. (1991). Parental divorce and adult well-being: A meta analysis. Journal of Marriage and The Family, 53(1), 43-58.

Brown, B. (1990). Peer groups and peer cultures. In S. S. Feldman \& G. R. Elliot (Eds.), At the threshold: The developing adolescent (p. 171-196). Cambridge, MA: Harvard University Press.

Büyüköztürk, Ş. (2014). Sosyal bilimler için veri analizi el kitabı (19.Basım). Ankara: Pegem Akademi. 
Büyüköztürk, Ş., Kılıç-Çakmak, E., Akgün, Ö. E., Karadeniz, Ş. ve Demirel, F. (2016). Bilimsel araştırma yöntemleri (21.Basım). Ankara: Pegem Akademi.

Calmeiro, L., Camacho, I. ve Matos, M. G. (2018). Life satisfaction in adolescents: The role of individual and social health assets. The Spanish Journal of Psychology, 21(e23), 1-8. doi:10.1017/sjp.2018.24

Cao, H., Sun, Y., Wan, Y., Hao, J. ve Tao, F. (2011). Problematic Internet use in Chinese adolescents and its relation to psychosomatic symptoms and life satisfaction. BMC public health, 11(1), 802. doi:10.1186/1471-2458-11-802

Clasen, D. R. ve Brown, B. B. (1985). The multidimensionality of peer pressure in adolescence. Journal of Youth and Adolescence 14(6), 451-468. doi:10.1007/BF02139520

Cohen, J. (1988). Statistical power analysis fort he behavioral sciences (2.Basım). Hillsdale, NJ: Erlbaum.

Çeçen-Eroğul, A. R. ve Türk, S. B. (2013). Ergenlerde çocukluk örselenme yaşantıları ve öfke ifade tarzları ile benlik saygısı ve yaşam doyumu arasındaki ilişkilerin incelenmesi. Journal of Human Sciences, 10(1), 1421-1439.

Çelik, E., Arıcı-Özcan, N. A. ve Turan, M. E. (2014). Ergenlerin yaşam doyumunu algılanan okul yetersizliğinin, sosyal kaynaklı mükemmeliyetçiliğin ve kendini değerlendirmenin yordaması. Eğitimde Kuram ve Uygulama, 10(4), 1143-1155.

Çivitçi, A. (2009). İköğretim öğrencilerinde yasam doyumu: Bazı kişisel ve ailesel özelliklerin rolü. Uludă̆ Üniversitesi Eğitim Fakültesi Dergisi, 22(1), 29-52.

Çivitçi, N., Çivitçi, A. ve Fiyakalı, N. C. (2009). Loneliness and life satisfaction in adolescents with divorced and non-divorced parents. Kuram ve Uygulamada Ĕ̈itim Bilimleri, 9(2), 513-525.

Çokluk, Ö., Şekercioğlu, G. ve Büyüköztürk, Ş. (2014). Sosyal bilimler için çok değgişkenli istatistik SPSS ve LISREL uygulamaları (3.Basım). Ankara: Pegem Akademi.

Demir, I., Peker-Özköklü, D. ve Aygün-Turğut, B. (2015). Ergenlerin problemli internet kullanımının yordanmasında denetim odağı ve yaşam doyumunun rolü. Mersin Üniversitesi Eğitim Fakültesi Dergisi, 11(3), 720-731. doi:10.17860/efd.02132

Demo, D. H. ve Acock, A. C. (1996). Family structure, family process, and adolescent well-being. Journal of Research on Adolescence, 6(4), 457-488.

Diener, E. D., Emmons, R. A., Larsen, R. J. ve Griffin, S. (1985). The satisfaction with life scale. Journal of personality assessment, 49(1), 71-75. doi:10.1207/s15327752jpa4901_13 
Diener, E., Oishi, S. ve Tay, L. (2018). Advances in subjective well-being research. Nature Human Behaviour, 2(4), 253. doi:10.1038/s41562-018-0307-6

Dingiltepe, T. (2009). Parçalanmış ve tam aileye sahip ergenlerin yasam doyumu düzeyleri ile yasam kalite düzeylerinin karsilaştırlması (Yayımlanmamış Yüksek Lisans Tezi). Çukurova Üniversitesi, Sosyal Bilimler Enstitüsü, Adana.

Erol, M. (2017). Genç yetişkinliğin öncesinde olan ergenlerin yaşam doyumu: "Utangaçlık" ve "öz yeterlik algısı"nın rolü. Türk Psikiyatri Dergisi, 28(2), 95103. doi:10.5080/u13563

Fields, A. (2005). Discovering statistics using SPSS (2.Basım). Beverly Hills: Sage Publications.

Fischhoff, B., Crowell, N. A. ve Kipke, M. (1999). Adolescent decision making: Implications for prevention programs. Washington: National Academies Press.

Funk, B. A., Huebner, E. S. ve Valois, R. F. (2006). Reliability and validity of a brief life satisfaction scale with a high school sample. Journal of Happiness Studies, 7(1), 41-54. doi:10.1007/s10902-005-0869-7

Gilman, R. ve Huebner, E. S. (2006). Characteristics of adolescents who report very high life satisfaction. Journal of Youth and Adolescence, 35(3), 311-319. doi:10.1007/s10964-006-9036-7

Gün, Z. ve Bayraktar, F. (2008). Türkiye'de iç göçün ergenlerin uyumundaki rolü. Türk Psikiyatri Dergisi, 19(2), 167-176.

Huebner, E. S. (1991). Correlates of life satisfaction in children. School Psychology Quarterly, 6(2), 103-111. doi:10.1037/h0088805

Huebner, E. S., Drane, W. ve Valois, R. F. (2000). Levels and demographic correlates of adolescent life satisfaction reports. Social Psychology International, 21(3), 281-292. doi:10.1177/0143034300213005

Huebner, E. S., Suldo, S. M., Smith, L. C. ve McKnight, C. G. (2004). Life satisfaction in children and youth: Empirical foundations and implications for school psychologists. Psychology in the Schools, 41(1), 81-93. doi:10.1002/pits.10140

Huebner, E. S., Valois, R. F., Paxton, R. J. ve Drane, J. W. (2005). Middle school student's perceptions of quality of life. Journal of Happiness Studies, 6(1), 15-24. doi:10.1007/s10902-004-1170-x

Karasar, N. (2012). Bilimsel araştırma yöntemi (24.Basım). Ankara: Nobel Yayın Dağıtım.

Kelley, B. S. ve Miller, L. (2007). Life satisfaction and spirituality in adolescents. In Research in the Social Scientific Study of Religion, Volume 18 (pp. 233-261). Brill. doi:10.1163/ej.9789004158511.i-301.91 
Kermen, U., İçin-Tosun, N. ve Doğan, U. (2016). Yaşam doyumu ve psikolojik iyi oluşun yordayıcısı olarak sosyal kaygı. Eğitim Kuram ve Uygulama Araştırmalan Dergisi, 2(1), 20-29.

Kıran, B. (2002). Akran baskısı düzeyi farkh olan öğrencilerin risk alma, sigara içme davranışı ve okul başarlarının incelenmesi. Yayımlanmamış Doktora Tezi, Gazi Üniversitesi, Eğitim Bilimleri Enstitüsü, Ankara.

Kıran-Esen, B. (2003). Akran baskısı ölçeği'nin geliştirilmesi: geçerlik ve güvenirlik çalışması. Eğitim Bilimleri ve Uygulama, 2(3), 65-76.

Kirk, R. E. (1996). Practical significance: A concept whose time has come. Educational and Psychological Measurement, 56(5), 746-759. doi:10.1177/0013164496056005002

Konu, A. I., Lintonen, T. P. ve Rimpellä, M. K. (2002). Factors associated with school children's general subjective well-being. Health Education Research, 17(2), 155-165. doi:10.1093/her/17.2.155

Köse, N. (2016). Ergenlerde internet bağımlılı̆gnın yaşam doyumuna etkisi. Elektronik Mesleki Gelişim ve Araştırmalar Dergisi, 4(1), 15-23. doi:25.1234/0123456789

Lerner, R. M., Tirrell, J. M., Dowling, E. M., Geldhof, G. J., Gestsdóttir, S., Lerner, J. V., ... Sim, A. T. (2019). The end of the beginning: Evidence and absences studying positive youth development in a global context. Adolescent Research Review, 4(1), 1-14. doi:10.1007/s40894-018-0093-4

Leung, C. Y. W., McBride-Chang, C. ve Lai, B. P. Y. (2004). Relations among maternal parenting style, academic competence, and life satisfaction in Chinese early adolescents. The Journal of Early Adolescence, 24(2), 113-143. doi:10.1177/0272431603262678

Little, R. J. (1988). A test of missing completely at random for multivariate data with missing values. Journal of the American statistical Association, 83(404), 11981202.

Loesel, F., Bliesener, T. ve Koeferl, P. (1989). On the concept of "invulnerability": evaluation and first results of the Bielefeld project. In M. Bambring, F. Loesel ve H. Skowronek (Eds.), Children at risk: Assessment, longitudinal research, and intervention (p. 186-219). Berlin: de Gruyter.

Marques, S. C., Lopez, S. J. ve Mitchell, J. (2013). The role of hope, spirituality and religious practice in adolescents' life satisfaction: Longitudinal findings. Journal of Happiness Studies, 14(1), 251-261. doi:10.1007/s10902-012-9329-3

Maslow, A. H. (2013). Toward a psychology of being. New York: Simon and Schuster. 
Masten, A. S. (1994). Resilience in individual development: Successful adaptation despite risk and adversity. In M. C. Wang and E. Gordon (Eds.), Educational resilience in inner city America: Challenges and prospects (pp. 3-25). New York: Erlbaum.

Masten, A. S., Hubbard, J. J., Gest, S. D., Tellegen, A., Garmezy, N. ve Ramirez, M. (1999). Competence in the context of adversity: Pathways to resilience and maladaptation from childhood to late adolescence. Development and Psychopathology, 11(1), 143-169. doi:10.1017/S0954579499001996

McKnight, C. G., Huebner, E. S. ve Suldo, S. (2002). Relationships among stressful life events, temperament, problem behavior, and global life satisfaction in adolescents. Psychology in the Schools, 39(6), 677-687. doi:10.1002/pits.10062

Mertler, C. A. ve Vannatta, R. A. (2016). Advanced and multivariate statistical methods: Practical application and interpretation (6.Basim). New York: Taylor \& Francis.

Morsünbül, Ü. (2013). Benlik kurgularının ergenlerin yaşam doyumu ve depresyon düzeylerine olan etkisi. Klinik Psikiyatri, 16, 18-26.

Myers, D. G. ve Diener, E. (1995). Who is happy? Psychological Science, 6(1), 10-19. doi:10.1111/j.1467-9280.1995.tb00298.x

Ogurlu, Ü., Birben, F. Y., Öpengin, E. ve Yalın, H. S. (2016). Üstün zekâlı ergenlerde yalnızlık ve yaşam doyumu ilişkisi. Kocaeli Üniversitesi Sosyal Bilimler Dergisi, (31), 161-184.

Oliva, A., Rios, M., Antolin-Suarez, L., Parra, A., Hernando, A. ve Pertegal, M. A. (2010). Beyond the deficit: Building a model of positive youth development. Infancia y Aprendizaje, 33(2), 223-234. doi:10.1174/021037010791114562

Özen, Y. ve Gül, A. (2007). Sosyal ve eğitim bilimleri araştırmalarında evrenörneklem sorunu. Atatürk Üniversitesi Kazım Karabekir Eğitim Fakültesi Dergisi, (15), 394-422.

Paxton, R. J., Valois, R. F., Huebner, E. S. ve Drane, J. W. (2006). Opportunity for adult bonding/meaningful neighborhood roles and life-satisfaction among USA middle school students. Social Indicators Research,79(2), 291-312. doi:10.1007/s11205-005-4129-3

Povedano-Diaz, A., Muñiz-Rivas, M. ve Vera-Perea, M. (2020). Adolescents' life satisfaction: The role of classroom, family, self-concept and gender. International Journal of Environmental Research and Public Health, 17(1), 19. doi:10.3390/ijerph17010019

Proctor, C. L., Linley, P. A. ve Maltby, J. (2009). Youth life satisfaction: A review of the literature. Journal of happiness studies, 10(5), 583-630. doi:10.1007/s10902008-9110-9 
Raboteg-Šarić, Z., Brajša-Žganec, A. ve Šakić, M. (2009). Life satisfaction in adolescents: The effects of perceived family economic status, self-esteem and quality of family and peer relationships. Društvena istraživanja: časopis za opća društvena pitanja, 18(3), 547-564.

Raboteg-Šarić, Z. ve Šakić, M. (2014). Relations of parenting styles and friendship quality to self-esteem, life satisfaction and happiness in adolescents. Applied Research in Quality of Life, 9(3), 749-765. doi:10.1007/s11482-013-9268-0

Rey, L., Extremera, N. ve Pena, M. (2011). Perceived emotional intelligence, selfesteem and life satisfaction in adolescents. Psychosocial Intervention, 20(2), 227-234. doi:10.5093/in2011v20n2a10

Richardson, S. ve McCabe, M. P. (2001). Parental divorce during adolesence and adjustment in early adulthood. Adolescence, 36(143), 467-489.

Ryan, A. M. (2000). Peer groups as a context for the socialization of adolescents' motivation, engagement, and achievement in school. Educational Psychologist, 35(2), 101-111. doi:10.1207/S15326985EP3502_4

Santor, D. A., Messervey, D. ve Kusumakar, V. (2000). Measuring peer pressure, popularity, and conformity in adolescent boys and girls: Predicting school performance, sexual attitudes, and substance abuse. Journal of Youth and Adolescence, 29(2), 163-182. doi:10.1023/A:1005152515264

Savi-Çakar, F. ve Karataş, Z. (2017). Ergenlerin okula bağlanmalarının yordayıcıları olarak benlik saygısı, okul öfkesi ve yaşam doyumu. Eğitim ve Bilim, 42(189), 121-136. doi:10.15390/EB.2017.6573

Shek, D. T. L. (1998). A longitudinal study of the relationship between family functioning and adolescent psychological well-being. Journal of Youth Studies, 1(2), 195-209. doi:10.1080/13676261.1998.10593006

Shek, D. T. L. (2005a). Paternal and maternal influences on the psychological wellbeing, substance abuse, and delinquency of Chinese adolescents experiencing economic disadvantage. Journal of Clinical Psychology, 61(3), 219-234. doi:10.1002/jclp.20057

Shek, D. T. L. (2005b). Perceived parental control processes, parent-child relational qualities, and psychological well-being in Chinese adolescents with and without economic disadvantage. The Journal of Genetic Psychology, 166(2), 171-188. doi:10.3200/GNTP.166.2.171-188

Sin, N. L. ve Lyubomirsky, S. (2009). Enhancing well-being and alleviating depressive symptoms with positive psychology interventions: A practice-friendly meta-analysis. Journal of clinical psychology, 65(5), 467-487 doi:10.1002/jclp.2059 
Suldo, S. M. ve Huebner, E. S. (2004). The role of life satisfaction in the relationship between authoritative parenting dimensions and adolescent problem behavior. Social Indicators Research, 66(1-2), 165-195. doi:10.1023/B:SOCI.0000007498.62080.1e

Süpçeler, B. (2016). Ergenlik döneminde algilanan sosyal destek ile yaşam doyumu ve özgüven ilişkisi, Yayımlanmamış Yüksek Lisans Tezi, Yakın Doğu Üniversitesi, Eğitim Bilimleri Enstitüsü, Lefkoşa.

Tabachnick, B. G., Fidell, L. S. ve Ullman, J. B. (2007). Using multivariate statistics (5.Basım). Boston, MA: Pearson.

Tümkaya, S., Çelik, M. ve Aybek, B. (2011). Lise öğrencilerinde boyun eğici davranışlar, otomatik düşünceler, umutsuzluk ve yaşam doyumunun incelenmesi. Çukurova Üniversitesi Sosyal Bilimler Enstitüsü Dergisi, 20(2), 77-93.

Ünal, A. Ö. (2011). Lise öğrencilerinin yaşam doyumlarmın bazı değişkenlere göre yordanması. Yayımlanmamış Yüksek Lisans Tezi, Karadeniz Teknik Üniversitesi, Sosyal Bilimler Enstitüsü, Trabzon.

Valois, R. F., Zullig, K. J., Huebner, E. S. ve Drane, J. W. (2001). Relationship between life satisfaction and violent behaviors among adolescents. American Journal of Health Behavior, 25(4), 353-366. doi:10.5993/AJHB.25.4.1

Valois, R. F., Zullig, K. J., Huebner, E. S. ve Drane, J. W. (2004). Life satisfaction and suicide among high school adolescents. Social Indicators Research, 66, 81-105. doi:10.1023/B:SOCI.0000007499.19430.2f

Wong, S. S. ve Lim, T. (2009). Hope versus optimism in Singaporean adolescents: Contributions to depression and life satisfaction. Personality and Individual Differences, 46(5-6), 648-652. doi:10.1016/j.paid.2009.01.009

Yetim, Ü. (1993). Life satisfaction: A study based on the organization of personal projects. Social Indicators Research, 29, 277-289.

Yiğit, H. (2010). Ergenlerin benlik saygılarnn yaşam doyumu ve bazı özlük nitelikleri açısından incelenmesi. Yayımlanmamış Doktora Tezi, Selçuk Üniversitesi, Eğitim Bilimleri Enstitüsü, Konya.

Zullig, K. J., Valois, R. F., Huebner, E. S., Oeltmann, J. E. ve Drane, J. W. (2001). Relationship between perceived life satisfaction and adolescents' substance abuse. Journal of Adolescent Health, 29(4), 279-288. doi:10.1016/S1054139X(01)00269-5

Zullig, K. J., Valois, R. F., Huebner, E. S. ve Drane, J. W. (2005). Associations among family structure, demographics and adolescent perceived life satisfaction. Journal of Child and Family Studies, 14(2), 195-206. doi:10.1007/s10826-005$5047-3$ 


\section{Kaynakça Bilgisi / Citation Information}

Kılınç, M. ve Uzun, K. (2020). Ergenlerin yaşam doyumlarının yordayıcıları olarak direkt ve dolaylı akran baskısı. OPUS-Uluslararası Toplum Araştırmaları Dergisi, 16(28), 1241-1271. DOI: 10.26466/opus.748254 